\title{
An Analysis of the Effects of School Practice Courses (School Experience, Teaching Practice) on Prospective Physical Education Teachers' Attitudes towards Physical Education Teaching as a Profession (Case of Düzce University)
}

\author{
Kadir Tiryaki $(\mathbb{D}$ \\ Faculty of Sport Sciences, Department of Physical Education and Sports Education, Düzce University Düzce, \\ Turkey. \\ Email:tiryakikadir27@hotmail.com
}

\begin{abstract}
The study is conducted to examine the effects of school practice courses on prospective physical education teachers' attitudes towards their professions. 73 pre-service teachers, 30 women and 43 men, who took teaching practice courses in the spring semester of 2018-2019, participated in the study at the Department of Physical Education and Sport Education, Faculty of Sports Sciences, Düzce University. As a pre-test and post-test, the 23-item " Attitude towards the Physical Education Teaching Profession " test consisting of the sub-dimensions of "love for the profession " and "professional anxiety" developed by Unlu (2011) was applied. SPSS 20.0 package program was used in the analysis the data. Paired Samples t-test was used for the analysis of pretest-posttest results. Independent Samples t-test was used in binary variables and One-Way ANOVA test was used in variables with three or more groups. Significance level was taken as $p<0.05$. In conclusion; the analyzes for the sub-dimensions of attitude to the physical education profession and total attitudes were compared, a significant difference in favor of the posttest in terms of love for the profession, professional anxiety and total attitudes towards the profession was observed. Regarding the gender variable, pre-test and post-test scores of female participants show they have a higher attitude towards love sub-dimension. According to the national athlete variable, the pretest and post-test scores of non-national teacher trainees are higher in the sub-dimension of love for the profession than nationals.
\end{abstract}

Keywords: School experience, Teaching practice, Physical education, Teacher trainees, Pre-service training, Attitude towards profession.

Citation | Kadir Tiryaki (2020). An Analysis of the Effects of School Practice Courses (School Experience, Teaching Practice) on Prospective Physical Education Teachers' Attitudes towards Physical Education Teaching as a Profession (Case of Düzce University). Asian Journal of Education and Training, 6(3): 397-405. History:

Received: 26 March 2020

Revised: 30 April 2020

Accepted: 2 June 2020

Published: 11 June 2020

Licensed: This work is licensed under a Creative Commons

Attribution 3.0 License (cc)

Publisher: Asian Online Journal Publishing Group
Funding: This study received no specific financial support

Competing Interests: The author declares that there are no conflicts of interests regarding the publication of this paper.

Transparency: The author confirms that the manuscript is an honest, accurate, and transparent account of the study was reported; that no vital features of the study have been omitted; and that any discrepancies from the features of the study have been omitted;
study as planned have been explained.

Ethical: This study follows all ethical practices during writing.

\section{Contents}

1. Introduction

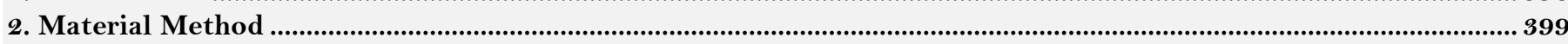

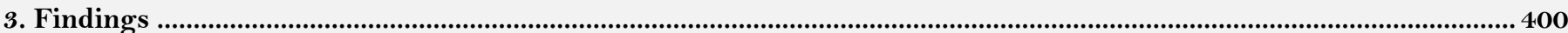

4. Discussion and Conclusion........................................................................................................................................... 403

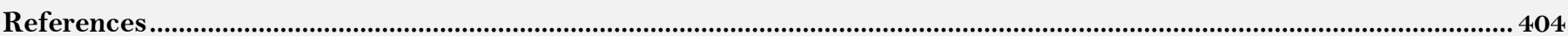




\section{Contribution of this paper to the literature}

This study contributes to the existing literature by examining the effects of school practice courses on prospective physical education teachers' attitudes towards their professions.

\section{Introduction}

The education system is very important in terms of the development of young people, who are the guarantee of our future in every way. Teachers are the most important gear of the education system. Therefore, teacher training programs, how the courses and school practices in these programs are planned and how much they contribute are highly important.

The Turkish society needs well-educated teachers with the capacity to educate people with the qualifications required by the modern times and a training that can respond to the rapidly developing and changing environment of the time it is in. Because teachers are the basic element of education and "the power and future of a country depend on the ability and success of its teachers Ataünal (1994).

Teachers are one of the most important elements of the education system, affected by the system and affecting it at the same time (Ira, 2004).

One of the most important aspects of teaching profession is that teachers be trained effectively during the preservice training process (Saritas, 2007).

In the teacher training process, besides the theoretical education received by teacher trainees in faculties, the experiences gained in practice schools play a very important role (Gökçe \& Demirhan, 2005).

Education is one of the most important stages of human life, and it is the most important power that shapes and changes the future of a society and ensures the political, economic and social development of countries. Countries have faced the obligation to organize, determine the principles, control and plan educational and training institutions to guide their future throughout their history (Akyüz, 2012).

In this sense, programs and departments that train teachers need to train prospective teachers with certain professional competencies. Field knowledge is one of the primary qualifications of teachers (Yeşildere \& Türnüklü, 2007). Considering that the framework program implemented by Council of Higher Education (COHE) is implemented in the faculties of education and teacher training schools of universities, it is seen that the competencies that are targeted to be acquired by teacher trainees through this program are the same for all education faculties and teacher training schools (Cakır, 2005).

Teaching Practice of the Ministry of National Education has been defined as the course where practical activities are discussed and evaluated, aiming to gain teaching skills in the classroom together with management and extracurricular activities and enabling teacher trainees to teach a specific lesson or lessons in a planned way (Ministry of National Education, 2018).

The Teaching Practice course consists of planned observations and activities aimed at introducing certain roles, tasks and professional standards that make up the teaching profession to prospective teachers through practice activities in practice schools. In the physical education and sports teaching undergraduate program, teaching practices are carried out in primary education, high school and equivalent schools for one semester in the 8 th semester of faculties that train teachers. The students participate in the practice as teacher and continue with various experiences and take on certain responsibilities. Some of these experiences are gained through observations made in the environment, in the school and in the classroom. Thus, the teacher trainees familiarize with the physical, managerial and educational aspects of the school where they practice (Yalçın, 1999).

Teaching practices aim to prepare prospective teachers for the profession by providing the opportunity to apply the knowledge, skills and attitudes in teacher training programs to be used in a real environment. It is known that prospective teachers studying in physical education programs, as in all areas where teachers are trained, encounter many problems during their teaching practice courses (Hergüner, Arslan, \& Dündar, 2002; Kalkavan, Kerez, Suiçmez, \& Bektaş, 2001; Sirin, Cağlayan, \& Cetin, 2007; Taskin, Baştuğ, \& Çetin, 2003).

The Ministry of National Education has defined School Experience as a course in the faculty curriculum that enables prospective teachers to correctly perceive and adopt the teaching profession and as the opportunity to get to know the daily organization in schools, the daily life in schools, to examine the educational environments, to participate in extra-curricular activities, to observe experienced teachers on the job, to work with students individually and in small groups, and to gain short-term teaching experiences (Ministry of National Education, 1998).

In line with this, School Experience and Teaching Practice courses are among the courses that provide the opportunity to apply the theoretical knowledge included in the education faculty teacher training programs in a real environment (Gökmen, 2015).

It has been observed that especially the teachers who are new to the profession face basic problems about classroom management, student evaluation, application of appropriate materials, the techniques of asking questions, student motivation and catering for individual difference (Azar, 2003; Kaya. \& Samanc1, 2013).

With the restructuring of the 1997- 1998 education faculties in Turkey, teacher training process underwent very significant changes. With the Education Faculty-Practice School Cooperation Program, which was introduced as a result of the regulations in teacher training in 2006, it was aimed to gain the theoretical information created in the learning processes in real environment by increasing the time allocated to the application (COHE, 2007). As a result of these regulations, the necessity of school experience and teaching practice courses emerged. At the meeting where the teacher training programs were promoted on May 16, 2018 Prof. Dr. Yekta SARAC, the president of Council of Higher Education said; " Previously, teacher training undergraduate programs were updated in 1998 and 2006 under the coordination of COHE. In addition to various studies, evaluations and reports prepared about the implementation of the programs over time, the General Competencies and Teacher Strategy Document (2017-2023) of the Teacher Profession developed by the Ministry of National Education were taken into consideration in the updating of the programs. " Consequently, instead of the school experience course in the sixth semester, Teaching Practice Course I was introduced. 
The subjects that are the basis for appointment as teachers in Turkey and the higher education programs to be graduated for each field teacher have been determined by the Ministry of Education, Education and Discipline Board. Under these new regulations, the graduates of Physical Education and Sports Teaching departments and the School of Physical Education and Sports and Faculty of Sport Sciences, and those who completed the Department of Physical Education and Pedagogical Formation Program and those who completed Pedagogical Formation Training Certificate Program carried out with the collaboration of Ministry of National Education and Council of Higher Education could be appointed as teachers (Ministry of National Education, 2014).

Physical education is a whole body of activities performed through play to achieve the efficiency power required by the age and genetic potential of the physical, spiritual and mental qualities that make up the whole human being (Aracı \& Aracı, 2014). Physical education and sports activities can be shown as the most appropriate and important training tool in the training and development of the physical and mental structure of people, especially children and young people. Sports makes an important contribution to the cultivation of especially young generations with a high sense of national unity and solidarity and people who are constructive, qualified, creative, and thus to economic, social and cultural development (Yetim, 2015).

It is today's requirements that individuals be able to adapt to the rapidly changing and developing world with their free will, express themselves, and be raised as harmonious, self-confident, productive, innovative and creative individuals. It is important to plan physical education as qualified for these requirements (Canakay, 2006).

It is important for our young people, who are the guarantee of our future, to develop both physically and mentally, to look forward to the future with hope. The teaching profession is a critical profession and one of the most important roles is taken by physical education teachers.

To sum up, in this study, it is aimed to determine how school practice courses (school experience, teaching practice) affect the attitudes of physical education teacher trainees towards their profession.

In literature, there are various studies about the competencies and attitudes of prospective teachers towards the profession (Abbasoğlu, 2011; Akar, 2007; Bozdoğan, Aydın, \& Yıldırım, 2007; Demirtaş, Cömert, \& Özer, 2011; İlter, 2009; Işılöz, Diçer, \& Kılınç, 2016; Islam \& Imamoglu, 2019; Kahyaoğlu \& Ateş, 2007; Kaya, 2004; Keskin, 2013; Oksüzoğlu, 2009; Ozbek, Kâhyaoğlu, \& Özgen, 2007; Şirin \& Cesur, 2010). However, studies about the effects of school practice courses (school experience, teaching practice) on the attitudes of physical education teacher trainees to physical education teaching profession have not been found. In this sense, the study is important in terms of its contribution to the literature.

\section{Material Method}

\subsection{Purpose of the Study}

The aim of this study is to examine the effects of school practice courses (school experience, teaching practice) on the attitudes of physical education teacher trainees towards physical education teaching as a profession.

\subsection{Statement of the Problem}

Do school practice courses (school experience, teaching practice) have an impact on the attitudes of physical education teacher trainees towards physical education teaching as a profession?

\subsection{Study Group}

The study group consists of a total of 73 prospective teachers, 30 female and 43 male, who were educated in the Department of Physical Education and Sports Education at the Faculty of Sports Sciences of Düzce University and who took the school experience and teaching practice course in the spring term of 2018-2019 academic year. The percentages of the students participating in the study based on the variables are given in Table 1.

\begin{tabular}{|c|c|c|c|}
\hline Variables & & $\mathbf{N}$ & $\%$ \\
\hline \multirow{2}{*}{ Gender } & Woman & 30 & 41,1 \\
\hline & Male & 43 & 58,9 \\
\hline \multirow{2}{*}{ National Athlete } & Yes & 41 & 56,2 \\
\hline & No & 32 & 43,8 \\
\hline \multirow{4}{*}{ Experience in sports } & $1-5$ years & 9 & 12,3 \\
\hline & $6-10$ years & 36 & 43,3 \\
\hline & $11-15$ years & 23 & 31,5 \\
\hline & 16 and over & 5 & 6,8 \\
\hline \multirow{4}{*}{ Profession of father } & Civil Servant & 15 & 20,5 \\
\hline & Worker & 20 & 27,4 \\
\hline & Self-employment & 18 & 24,7 \\
\hline & Retired & 20 & 27,4 \\
\hline \multirow{5}{*}{ Profession of Mother } & Housewife & 46 & 63,0 \\
\hline & Civil Servant & 8 & 11,0 \\
\hline & Worker & 10 & 13,7 \\
\hline & Self-employment & 4 & 5,5 \\
\hline & Retired & 5 & 6,8 \\
\hline
\end{tabular}

In Table 1, the variables of the prospective physical education teachers participating in the study are as follows; $41.1 \%$ (n: 30 ) women, $58.9 \%$ (n: 43) men, 56.2\% (n: 41 ) national athletes, $43.8 \%$ (n: 32 ) non-national athletes, $12 \%, 3$ (n: 9 ) 1-5 years, $43.3 \%$ (n: 36) 6-10 years, $31.5 \%$ (n: 23) $11-15$ years, $6.8 \%$ (n: 5 ) 16 years and over. Moreover, when we look at the variable of profession of father; $20.5 \%$ (n: 15 ) civil servants, $27.4 \%$ (n: 20) workers, $24.7 \%$ (n: 18 ) selfemployed, $27.4 \%$ (n: 20) retired; and the mother's profession is $63.0 \%$ (n: 46 ) housewives, $11.0 \%$ (n: 8) civil servants, 13.7\% (n: 10 ) workers, $5.5 \%$ (n: 4) self-employed and 6.8\% (n: 5 ) retired. 


\subsection{Model of the Research}

Experimental research model (pre-test and post-test) was used in this study to analyze the effects of school practice courses (school experience, teaching practice) on the attitudes of prospective physical education teachers towards the physical education teaching profession. In a research, an experimental model is generally used to measure variables (properties that can be measured quantitatively and take different values) and to reveal the cause-effect relationships between these variables. Experimental model is defined as a type of research that involves the application of the factor to be measured under certain rules and conditions, measuring the responses of the subjects to the factor and comparing the results obtained (Cepni, 2007).

\subsection{Research Method}

In teacher training programs, the 3rd grade students in the 6th semester and the 4th grades in the 8 th semester take the teaching practice course. In this study, prior to the study with the students taking these courses; personal information form and the attitude scale to the physical education teaching profession created by the researcher were applied face to face as a pre-test. At the end of the practice lessons, which continued for 14-week in practice schools, the attitude scale to the Physical Education Teaching profession was reapplied face to face as a post-test.

\subsection{Data Collection Tools}

In the study; "Attitude Scale towards Physical Education Teaching Profession" developed by Unlu (2011) and "Personal Information Form" created by the researcher were used.

The "love for the profession" sub-dimension consists of 13 items and the "professional anxiety" sub-dimension consists of ten items making a total of 23 items. The scale is designed in a five-point Likert type. While scoring in positive items $(19,24,10,17,16,7,5,25,1,23,4,21,8)$ in the scale, it is done as 5-4-3-2-1, while in negative items $(14,2,12,18,6,22,11,13,3,15)$ scoring was done as 1-2-3-4-5.

The lowest score to be taken from the scale is 23 and the highest score is 115 . In order to evaluate the scores obtained from the scale, the interval coefficient was determined. Accordingly, 23-41 score range is "very low attitude", 42-60 score range is "low attitude", 61- 79 score range is "medium attitude", 80-98 score range is "high attitude" and 99-115 score range is "very high attitude". The high score to be obtained from the scale shows the positive attitude towards physical education teaching profession. The scale is also suitable for calculating over averages. The range coefficient determined for calculating over the averages is; $1-1.80$ score range is "very low attitude", 1.81-2.60 score range is "low attitude", 2.61-3.40 score range is "moderate attitude", 3.41-4.20 score range is "high attitude", 4.21-5.00 score range is "very high attitude" Unlu (2011).

\subsection{Data Analysis}

The data obtained in the study were analyzed using the SPSS 20.0 package program. Descriptive statistics test was used in distributions according to demographic characteristics between the groups. Paired Samples t test was used for the analysis of pretest-posttest results. Independent Samples t test was used in binary variables and OneWay ANOVA test was used in variables with three or more groups. Significance level was determined as p <0.05.

\section{Findings}

Table-2. The results of Paired Samples Statistics test conducted to compare the prospective physical education in terms of their attitudes towards physical education teaching profession according to the subdimensions of the scale and the total attitude averages.

\begin{tabular}{|c|c|c|c|c|c|}
\hline Love for Profession sub-dimension & $\mathbf{N}$ & $\bar{X}$ & $\mathbf{S}$ & $\bar{t}$ & $\bar{p}$ \\
\hline Love for profession pretest & 73 & 52,89 & 6,165 & \multirow{2}{*}{-4.751} & \multirow{2}{*}{, $000 *$} \\
\hline Love for profession Posttest & 73 & 53,65 & 5,761 & & \\
\hline Professional Anxiety sub-dimension & $\mathbf{N}$ & $\bar{X}$ & $\overline{\mathbf{S}}$ & $\bar{t}$ & $\bar{p}$ \\
\hline Professional Anxiety Pretest & 73 & 37,63 & 6,190 & \multirow{2}{*}{$-5,942$} & \multirow{2}{*}{, $000 *$} \\
\hline Professional Anxiety Posttest & 73 & 39,54 & 5,547 & & \\
\hline \multicolumn{6}{|c|}{ Attitude towards the profession } \\
\hline Total Attitude Pretest & 73 & 90,52 & 8,768 & \multirow{2}{*}{$-7,390$} & \multirow{2}{*}{, $000 *$} \\
\hline Total Attitude Posttest & 73 & 93,20 & 8,333 & & \\
\hline
\end{tabular}
Note: ${ }^{*} \mathrm{p}<0.01$.

In Table 2, when the pre-test post-test mean scores of the attitude sub-dimensions and total attitudes of the physical education teacher trainees towards physical education profession are compared, there is a significant difference in favor of the posttest among love for the profession $(p<0.01)$, professional anxiety $(p<0.01)$ and total attitudes towards the profession $(\mathrm{p}<0.01)$.

Table-3. T-test for independent groups according to the pre-test scores of attitudes towards physical education teaching profession by gender variable.

\begin{tabular}{|c|c|c|c|c|c|c|}
\hline \multicolumn{2}{|l|}{ Gender } & $\mathbf{N}$ & $\mathbf{X}$ & $\mathbf{S}$ & $t$ & p \\
\hline \multirow[t]{2}{*}{ Love for profession } & Woman & 30 & 54,7667 & 3,46095 & \multirow{2}{*}{2,50} & \multirow[t]{2}{*}{, $015^{*}$} \\
\hline & Male & 43 & 51,5814 & 7,25466 & & \\
\hline \multirow[t]{2}{*}{ Professional Anxiety } & Woman & 30 & 37,0000 & 5,86633 & \multirow[t]{2}{*}{66,02} & \multirow[t]{2}{*}{,464 } \\
\hline & Male & 43 & 38,0698 & 6,43797 & & \\
\hline \multirow[t]{2}{*}{ Total attitude } & Woman & 30 & 91,7667 & 6,08380 & \multirow{2}{*}{69,53} & \multirow[t]{2}{*}{,273 } \\
\hline & Male & 43 & 89,6512 & 10,21643 & & \\
\hline
\end{tabular}

Note: ${ }^{*} \mathrm{p}<0.05$ 
When Table 3 is examined, there is no difference between anxiety and total attitudes towards profession in terms of gender variable according to the pretest scores of attitudes towards the profession of physical education, while there is a significant difference in favor of female physical education teacher trainees in the sub-dimension of love for the profession $(\mathrm{p}<0.05)$.

\begin{tabular}{|c|c|c|c|c|c|c|}
\hline \multicolumn{2}{|l|}{ Gender } & $\mathbf{N}$ & $\mathbf{X}$ & $\mathbf{S}$ & $t$ & $\bar{p}$ \\
\hline \multirow[t]{2}{*}{ Love for profession } & Woman & 30 & 55,2333 & 3,59773 & \multirow{2}{*}{2.20} & \multirow{2}{*}{,O31* } \\
\hline & Male & 43 & 52,5581 & 6,70573 & & \\
\hline \multirow[t]{2}{*}{ Professional Anxiety } & Woman & 30 & 38,8667 & 4,96702 & \multirow{2}{*}{,- 875} & \multirow{2}{*}{,375 } \\
\hline & Male & 43 & 40,0233 & 5,93010 & & \\
\hline \multirow[t]{2}{*}{ Total attitude } & Woman & 30 & 94,1000 & 5,89184 & \multirow{2}{*}{,- 764} & \multirow{2}{*}{, 447} \\
\hline & Male & 43 & 92,5814 & 9,70084 & & \\
\hline
\end{tabular}

\section{Note: ${ }^{*} \mathrm{p}<0.05$.}

When Table 4 is examined, according to the posttest mean scores of attitudes towards physical education teaching profession, there is no difference between anxiety and total attitudes towards profession in terms of gender variable, while there is a significant difference in favor of female physical education teacher trainees in the sub-dimension of love for profession $(\mathrm{p}<0.05)$.

Table-5. T-test for independent groups according to the pre-test scores of attitudes towards physical education teaching profession according to the national athlete status variable

\begin{tabular}{|c|c|c|c|c|c|c|}
\hline \multicolumn{2}{|c|}{ National athlete } & $\mathbf{N}$ & $\mathbf{X}$ & $\mathbf{S}$ & $\underline{t}$ & p \\
\hline \multirow[t]{2}{*}{ Love for profession } & Yes & 41 & 50,9024 & 7,16870 & \multirow[b]{2}{*}{57,88} & \multirow[b]{2}{*}{$001 *$} \\
\hline & No & 32 & 55,4375 & 3,17183 & & \\
\hline \multirow[t]{2}{*}{ Professional Anxiety } & Yes & 41 & 38,5122 & 5,23508 & \multirow[b]{2}{*}{54,85} & \multirow[b]{2}{*}{, 187} \\
\hline & No & 32 & 36,5000 & 7,16173 & & \\
\hline \multirow[t]{2}{*}{ Total attitude } & Yes & 41 & 89,4146 & 8,87123 & \multirow[b]{2}{*}{67,80} & \multirow[b]{2}{*}{,223 } \\
\hline & No & 32 & 91,9375 & 8,56451 & & \\
\hline
\end{tabular}

When Table 5 is examined, according to the pre-test scores of attitudes towards the profession of physical education in terms of national athlete variable, there is no difference between anxiety and total attitudes towards the profession, whereas there is a significant difference in favor of non-national physical education teacher trainees in the sub-dimension of love for the profession $(\mathrm{p}<0.05)$.

Table-6. T-test for independent groups according to the posttest scores of attitudes towards physical education teaching profession according to the national athlete status variable.

\begin{tabular}{|c|c|c|c|c|c|c|}
\hline \multicolumn{2}{|c|}{ National Athlete } & $\mathbf{N}$ & $\mathbf{X}$ & $\mathbf{S}$ & $\mathbf{t}$ & p \\
\hline \multirow[t]{2}{*}{ Love for profession } & Yes & 41 & 51,8780 & 6,69774 & \multirow{2}{*}{-3.43} & \multirow{2}{*}{, $001 *$} \\
\hline & No & 32 & 55,9375 & 3,11021 & & \\
\hline \multirow[t]{2}{*}{ Professional Anxiety } & Yes & 41 & 40,0732 & 4,68183 & \multirow{2}{*}{, 915} & \multirow{2}{*}{, 364} \\
\hline & No & 32 & 38,8750 & 6,50930 & & \\
\hline \multirow[t]{2}{*}{ Total attitude } & Yes & 41 & 91,9512 & 8,39033 & \multirow{2}{*}{$-1,46$} & \multirow{2}{*}{, 147} \\
\hline & No & 32 & 94,8125 & 8,10590 & & \\
\hline
\end{tabular}

When Table 6 is examined, according to the posttest mean scores of attitudes towards physical education teacher profession in terms of national athlete variable, there is no difference between anxiety and total attitudes towards profession, whereas there is a significant difference in favor of non-national physical education teacher trainees in the sub-dimension of love for profession $(\mathrm{p}<0.05)$.

Table-7. ANOVA test for independent groups based on the pre-test scores of attitudes towards physical education teaching profession according to the athlete year variable.

\begin{tabular}{|c|c|c|c|c|c|c|}
\hline \multicolumn{2}{|c|}{ Experience in Sport } & $\mathbf{N}$ & $\mathbf{X}$ & $\mathbf{S}$ & f & $p$ \\
\hline \multirow{5}{*}{ Love for Profession } & $1-5$ years & 9 & 53,5556 & 12,01157 & \multirow{5}{*}{,261 } & \multirow{5}{*}{, 85} \\
\hline & $6-10$ years & 36 & 53,0000 & 4,04263 & & \\
\hline & $11-15$ years & 23 & 52,9565 & 6,51905 & & \\
\hline & 16 or more years & 5 & 50,6000 & 3,36155 & & \\
\hline & Total & 73 & 52,8904 & 6,16568 & & \\
\hline \multirow{5}{*}{ Professional Anxiety } & $1-5$ years & 9 & 35,1111 & 8,43274 & \multirow{5}{*}{,878 } & \multirow{5}{*}{, 457} \\
\hline & $6-10$ years & 36 & 37,7500 & 5,92513 & & \\
\hline & $11-15$ years & 23 & 38,7826 & 5,80718 & & \\
\hline & 16 or more years & 5 & 36,0000 & 5,43139 & & \\
\hline & Total & 73 & 37,6301 & 6,19029 & & \\
\hline \multirow{5}{*}{ Total Attitude } & $1-5$ years & 9 & 88,6667 & 14,66288 & \multirow{5}{*}{,613 } & \multirow{5}{*}{, 609} \\
\hline & $6-10$ years & 36 & 90,7500 & 7,57958 & & \\
\hline & $11-15$ years & 23 & 91,7391 & 8,11966 & & \\
\hline & 16 or more years & 5 & 86,6000 & 7,26636 & & \\
\hline & Total & 73 & 90,5205 & 8,76880 & & \\
\hline
\end{tabular}

Note: $\mathrm{P}>0.05$ 
When Table 7 is examined, according to the pre-test scores of attitudes towards physical education teaching profession in terms of the variable of experience in sports, no difference is found between love for the profession, professional anxiety and total attitudes.

Table-8. ANOVA test for independent groups based on the posttest scores of attitudes towards physical

\begin{tabular}{|c|c|c|c|c|c|c|}
\hline \multicolumn{2}{|l|}{ Experience in sports } & $\mathbf{N}$ & $\mathbf{X}$ & $\overline{\mathbf{S}}$ & $\mathrm{f}$ & $\mathrm{p}$ \\
\hline \multirow[t]{5}{*}{ Love for Profession } & $1-5$ years & 9 & 54,6667 & 10,60660 & \multirow{5}{*}{, 201} & \multirow{5}{*}{, 895} \\
\hline & $6-10$ years & 36 & 53,8056 & 4,06953 & & \\
\hline & 11-15 years & 23 & 53,3043 & 6,28443 & & \\
\hline & 16 or more years & 5 & 52,4000 & 2,30217 & & \\
\hline & Total & 73 & 53,6575 & 5,76199 & & \\
\hline \multirow[t]{5}{*}{ Professional Anxiety } & $1-5$ years & 9 & 37,5556 & 7,24760 & \multirow{5}{*}{,990 } & \multirow{5}{*}{, 403} \\
\hline & $6-10$ years & 36 & 39,5833 & 5,08991 & & \\
\hline & 11-15 years & 23 & 40,7391 & 5,67464 & & \\
\hline & 16 or more years & 5 & 37,4000 & 4,72229 & & \\
\hline & Total & 73 & 39,5479 & 5,54788 & & \\
\hline \multirow[t]{5}{*}{ Total Attitude } & $1-5$ years & 9 & 92,2222 & 12,65679 & \multirow{5}{*}{,393 } & \multirow{5}{*}{, 758} \\
\hline & $6-10$ years & 36 & 93,3889 & 7,44226 & & \\
\hline & \begin{tabular}{|l|}
$11-15$ years \\
\end{tabular} & 23 & 94,0435 & 8,53590 & & \\
\hline & 16 or more years & 5 & 89,8000 & 4,81664 & & \\
\hline & Total & 73 & 93,2055 & 8,33326 & & \\
\hline
\end{tabular}

Note: $\mathrm{P}>0.05$

When Table 8 is examined, according to the posttest point averages of the attitudes towards physical education teaching profession in terms of the variable of experience in sports, no difference is found between love for the profession, professional anxiety and total attitudes.

\begin{tabular}{|c|c|c|c|c|c|c|}
\hline Profession of Mother & & $\mathbf{N}$ & $\mathbf{X}$ & $\mathbf{S}$ & f & p \\
\hline \multirow{6}{*}{ Love for profession } & Housewife & 46 & 53,3478 & 6,89675 & \multirow{6}{*}{1,613} & \multirow{6}{*}{, 181} \\
\hline & Civil Servant & 8 & 51,2500 & 3,99106 & & \\
\hline & Worker & 10 & 55,5000 & 2,95334 & & \\
\hline & Self-employment & 4 & 50,2500 & 2,50000 & & \\
\hline & Retired & 5 & 48,2000 & 6,14003 & & \\
\hline & Total & 73 & 52,8904 & 6,16568 & & \\
\hline \multirow{6}{*}{ Professional Anxiety } & Housewife & 46 & 37,5652 & 6,57825 & \multirow{6}{*}{, 925} & \multirow{6}{*}{, 455} \\
\hline & Civil Servant & 8 & 34,8750 & 4,51782 & & \\
\hline & Worker & 10 & 39,5000 & 5,58271 & & \\
\hline & Self-employment & 4 & 40,7500 & 1,50000 & & \\
\hline & Retired & 5 & 36,4000 & 7,73305 & & \\
\hline & Total & 73 & 37,6301 & 6,19029 & & \\
\hline \multirow{6}{*}{ Total attitude } & Housewife & 46 & 90,9130 & 9,55179 & \multirow{6}{*}{1,832} & \multirow{6}{*}{, 133} \\
\hline & Civil Servant & 8 & 86,1250 & 5,08324 & & \\
\hline & Worker & 10 & 95,0000 & 5,24934 & & \\
\hline & Self-employment & 4 & 91,0000 & 4,00000 & & \\
\hline & Retired & 5 & 84,6000 & 10,18823 & & \\
\hline & Total & 73 & 90,5205 & 8,76880 & & \\
\hline
\end{tabular}

When Table 9 is examined, according to the pre-test mean scores of attitudes towards physical education teaching profession in terms of the profession of mother variable, no difference is found between love for the profession, professional anxiety and total attitudes.

\begin{tabular}{|c|c|c|c|c|c|c|}
\hline Profession of mother & & $\mathbf{N}$ & $\mathbf{X}$ & $\mathbf{S}$ & $t$ & $p$ \\
\hline \multirow{6}{*}{ Love for profession } & Housewife & 46 & 54,0435 & 6,42203 & \multirow{6}{*}{1,519} & \multirow{6}{*}{,206 } \\
\hline & Civil Servant & 8 & 52,0000 & 4,00000 & & \\
\hline & Worker & 10 & 56,2000 & 2,85968 & & \\
\hline & Self-employment & 4 & 51,0000 & 2,70801 & & \\
\hline & Retired & 5 & 49,8000 & 5,71839 & & \\
\hline & Total & 73 & 53,6575 & 5,76199 & & \\
\hline \multirow{6}{*}{ Professional Anxiety } & Housewife & 46 & 39,8043 & 5,93902 & \multirow{6}{*}{,608 } & \multirow{6}{*}{,658 } \\
\hline & Civil Servant & 8 & 37,5000 & 3,85450 & & \\
\hline & Worker & 10 & 40,6000 & 5,12510 & & \\
\hline & Self-employment & 4 & 40,7500 &, 95743 & & \\
\hline & Retired & 5 & 37,4000 & 7,23187 & & \\
\hline & Total & 73 & 39,5479 & 5,54788 & & \\
\hline \multirow{6}{*}{ Total attitude } & Housewife & 46 & 93,8478 & 9,16992 & \multirow{6}{*}{1,668} & \multirow{6}{*}{, 167} \\
\hline & Civil Servant & 8 & 89,5000 & 4,86973 & & \\
\hline & Worker & 10 & 96,8000 & 4,98442 & & \\
\hline & Self-employment & 4 & 91,7500 & 3,59398 & & \\
\hline & Retired & 5 & 87,2000 & 9,23038 & & \\
\hline & Total & 73 & 93,2055 & 8,33326 & & \\
\hline
\end{tabular}

Note: $\mathrm{P}>0.05$ 
When Table 10 is examined, according to the posttest point averages of the attitudes towards physical education teaching profession in terms of the profession of mother variable, no difference is found between love for the profession, professional anxiety and total attitudes.

Table-11. ANOVA test for independent groups based on the pretest scores of their attitudes towards physical

\begin{tabular}{|c|c|c|c|c|c|c|}
\hline \multicolumn{2}{|l|}{ Profession of father } & $\mathbf{N}$ & $\mathbf{X}$ & $\mathbf{S}$ & f & p \\
\hline \multirow[t]{5}{*}{ Love for profession } & Civil Servant & 15 & 50,8000 & 5,00286 & \multirow{5}{*}{2,134} & \multirow{5}{*}{, 104} \\
\hline & Worker & 20 & 55,2500 & 3,98517 & & \\
\hline & Self-employment & 18 & 51,2778 & 8,70298 & & \\
\hline & Retired & 20 & 53,5500 & 5,45291 & & \\
\hline & Total & 73 & 52,8904 & 6,16568 & & \\
\hline \multirow[t]{5}{*}{ Professional Anxiety } & Civil Servant & 15 & 39,4667 & 4,45400 & \multirow{5}{*}{,868 } & \multirow{5}{*}{,462 } \\
\hline & \begin{tabular}{|l|} 
Worker \\
\end{tabular} & 20 & 36,2000 & 7,43817 & & \\
\hline & Self-employment & 18 & 38,1667 & 6,20484 & & \\
\hline & \begin{tabular}{|l|} 
Retired \\
\end{tabular} & 20 & 37,2000 & 5,96128 & & \\
\hline & Total & 73 & 37,6301 & 6,19029 & & \\
\hline \multirow[t]{5}{*}{ Total attitude } & Civil Servant & 15 & 90,2667 & 5,65012 & \multirow{5}{*}{, 168} & \multirow{5}{*}{,918 } \\
\hline & Worker & 20 & 91,4500 & 8,66010 & & \\
\hline & Self-employment & 18 & 89,4444 & 11,83823 & & \\
\hline & Retired & 20 & 90,7500 & 8,08426 & & \\
\hline & Total & 73 & 90,5205 & 8,76880 & & \\
\hline
\end{tabular}

When Table 11 is examined, according to the pretest scores of the attitudes towards physical education teaching profession in terms of the variable of the profession of father, no difference is found between love for the profession, professional anxiety and total attitudes.

\begin{tabular}{|c|c|c|c|c|c|c|}
\hline \multicolumn{2}{|l|}{ Profession of father } & $\mathbf{N}$ & $\mathbf{X}$ & $\mathbf{S}$ & $\mathrm{t}$ & $\mathbf{p}$ \\
\hline \multirow{5}{*}{ Love for profession } & Civil Servant & 15 & 51,5333 & 4,79385 & \multirow{5}{*}{1,867} & \multirow{5}{*}{, 143} \\
\hline & Worker & 20 & 55,8000 & 4,07302 & & \\
\hline & Self-employment & 18 & 52,6667 & 8,05861 & & \\
\hline & Retired & 20 & 54,0000 & 4,97361 & & \\
\hline & Total & 73 & 53,6575 & 5,76199 & & \\
\hline \multirow{5}{*}{ Professional Anxiety } & Civil Servant & 15 & 40,6667 & 4,33699 & \multirow{5}{*}{, 574} & \multirow{5}{*}{,634 } \\
\hline & Worker & 20 & 38,7000 & 6,85258 & & \\
\hline & Self-employment & 18 & 40,3333 & 5,16777 & & \\
\hline & Retired & 20 & 38,8500 & 5,39273 & & \\
\hline & Total & 73 & 39,5479 & 5,54788 & & \\
\hline \multirow{5}{*}{ Total attitude } & Civil Servant & 15 & 92,2000 & 4,47533 & \multirow{5}{*}{,242 } & \multirow{5}{*}{, 867} \\
\hline & Worker & 20 & 94,5000 & 8,84665 & & \\
\hline & Self-employment & 18 & 93,0000 & 11,11967 & & \\
\hline & Retired & 20 & 92,8500 & 7,53431 & & \\
\hline & Total & 73 & 93,2055 & 8,33326 & & \\
\hline
\end{tabular}

Note: $\mathrm{P}>0.05$

When Table 12 is examined, according to the posttest point averages of the attitudes towards physical education teaching profession in terms of the variable of the profession of father, no difference is found between love for the profession, professional anxiety and total attitudes.

\section{Discussion and Conclusion}

In this study, which was carried out in order to determine the attitudes of prospective physical education teachers towards physical education teaching as a profession, the effects of the variables of gender, national sportsmanship, experience in sports and profession of mother and father on physical education teaching attitudes were analyzed.

We see many studies conducted on the attitudes towards the teaching profession based on different variables in various countries in the world. In studies with similar findings to the ones in this study, it can be seen that prospective teachers exhibit positive attitudes towards teaching profession.

As a result of the analyzes in which the pre-test and post-test mean scores of attitude sub-dimensions and total attitudes of the prospective physical education teachers participating in the study were compared, it was found that there is a significant difference in favor of the post-test in terms of the attitude towards the profession. The pre-test scores of the physical education teacher trainees seem to show that they have high attitude towards the profession. As a result of the last post-test score averages of the school practice courses, it was determined that they show a very high attitude. Considering that they chose physical education teacher knowingly and willingly when they started the faculty of sports sciences, it can be an expected result that physical education teacher trainees who are included in intensive education programs in sports sciences will have high attitudes towards their professions. There are several prospective teachers, who are interested in different professions and cannot focus on theirs due to financial or other reasons even if they are educated in a department they have entered intentionally and willingly. It has been revealed that the pre-service training of physical education teachers in the study group have increased their attitudes towards their profession after school practice courses. 
Slaybaugh, Evans, and Byrd (2004) also showed that pre-service teachers have a very positive attitude in their study. Furthermore, Sharma and Dhaiya (2012) stated in their study that pre-service teachers were determined to have a positive attitude towards teaching profession. These results show that there are several studies that support the findings in this study. When we look at the results of pre-test and post-test analysis of the attitudes of physical education teacher trainees according to gender variable, there is no significant difference according to the professional anxiety sub-dimension and total attitude scores. In the sub-dimension of love for the profession, it is seen that female teacher trainees love teaching profession more than their male counterparts. When it comes to Turkey where there are more male physical education teachers and it is a mainly patriarchal society, we can say that female physical education teachers show that they love their professions and want to find a place in this field.

In another study, for example, Göktaş and Yanı (2015) stated that female teacher trainees show a more positive attitude compared to men in their study. Yalız (2010) revealed that female students' attitudes towards teaching profession are more positive attitudes than male students. In addition, Üzüm, Yalçın, Biçer, Yüktaşır, and Yıldırım (2015) put forward that female physical education teacher trainees' attitudes towards professions are higher than males. Islam and Imamoglu (2019) found that female physical education teacher trainees scored higher in the love of the profession sub-dimension than male physical education teacher trainees, but this difference was not a statistically significant difference. These are some of the studies from the related literature that support this study.

When we examine the results of pretest and posttest analysis according to the national athlete status variable, we see that while there is no significant difference in the pre-test and post-test results in anxiety and total attitudes towards the profession, in the sub-dimension of love for the profession, both in the pre-test and post-test results, there is a significant difference in favor of physical education teacher trainees who are national athletes. Those who are national athletes seem to love their professions more than those who are not national athletes. Prospective teachers who are athletes at the highest level in their branch at the national level tend to love teaching profession more. Islam and Imamoglu (2019) suggest that when the physical education teacher trainees with a branch and those without a branch are compared in terms of their attitudes to the physical education teaching profession, the teacher trainees with a branch seem to have higher attitudes than those without a branch. Eroğlu (2013) argued that that the physical education teacher trainees engaged in team sports have higher attitudes towards teaching profession compared to those engaged in individual sports.

In this study, it has been observed that the attitudes of physical education teacher trainees towards physical education teaching profession do not make a statistically significant difference according to the experience in sports variable. Teacher trainees who have 1-5 years, 6-10 years 11-15 years and over 16 years of experience have increased their attitudes towards their profession after school practice courses, but this shows that this increase does not make a statistically significant difference in terms of sportsmanship duration.

According to the variables of the profession of father and the profession, the average scores of the pre-service physical education teacher trainees seem to increase following the school experience. It was observed that this increase did not make statistically difference according to the analysis results.

As a result, regarding the attitudes of prospective physical education teachers, it can be said that there is a positive difference in favor of women in the gender variable and in favor of the national athletes according to the national athlete variable. In other variables (experience in sports, profession of father and profession of mother), school practice did not make any difference in attitudes towards teaching profession. In general terms, it is seen that the attitudes of the trainees in the study group towards the physical education profession are high in both the pre-test average scores and post-test scores. For this reason, we can say that school practice and education in the curriculum of sports science faculties increase the love of physical education teacher trainees for their professions and decrease their anxiety about the profession.

It is thought that this study, which was carried out on the effects of school practice courses on the attitudes of prospective teachers studying at the Faculty of Sports Sciences at Düzce University towards their profession, will contribute to the field of sports science.

Such studies can be applied to different universities and different study groups. Studies can be conducted with different variables by increasing the number of prospective teachers in the study group. It can be said that offering school practice courses in more semesters in higher education departments that train teachers will make great contributions to prospective teachers in terms of practice, familiarization with schools and communication with students.

\section{References}

Abbasoğlu, E. (2011). Investigation of physical education teacher candidates' attitude and self-esteem regarding teaching profession. Unpublished Master's Thesis. Karadeniz Technical University. Institute of Education Sciences. Trabzon.

Akar, E. (2007). The value and professional competencies of primary school social studies teaching senior students to teaching profession. Unpublished Master's Thesis. Afyon Kocatepe University. Social Sciences Institute. Afyonkarahisar.

Akyüz, Y. (2012). Turkish education history (pp. 12). Ankara: Pegem Academy.

Aracı, H., \& Aracı, Ş. (2014). Sports science teaching. Ankara: Graphic Printing.

Ataünal, A. (1994). Primary school teacher training problem in Turkey, M.E.B (pp. 11). Ankara: Higher Education General Directorate.

Azar, A. (2003). Reflections of views on school experiences and teaching practice. National Education Journal, 159(04.04), 18.

Bozdoğan, A. E., Aydın, D., \& Yıldırım, K. (2007). Teacher candidates' attitudes towards teaching profession. Ahi Evran University Kırşehir Journal of Education Faculty, 8(2), 83-97.

Cakır, Ö. (2005). Professional attitudes and vocational competency perceptions of anadolu university open education faculty english language teaching undergraduate program and education faculties english language teaching undergraduate program students. Inönü University Journal of Education Faculty, 6(9), 27-42.

Canakay, E. U. (2006). Developing an attitude scale for music theory course. Paper presented at the Declaration of National Music Education Symposium, Pamukkale University Faculty of Education, 26-28 April 2006, Denizli, Turkey.

Cepni, S. (2007). Introduction to research and project studies (3rd ed. Vol. 82). Trabzon: Celepler Matbaacılık.

COHE. (2007). Explanation about new programs to be implemented in education faculties. Retrieved from https://www.memurlar.net/haber/62021/egitim-fakultelerin-programi-degisti.html. [Accessed 06 March 2020].

Demirtaş, H., Cömert, M., \& Özer, N. (2011). Teachers' self-efficacy perceptions and attitudes towards teaching profession. Education and Science, 36(159), 96-111. 
Eroğlu, C. (2013). Self-efficacy and attitudes towards teaching profession of physical education teachers. Unpublished Master Thesis Aksaray University. Social Sciences Institute. Aksaray.

Gökçe, E., \& Demirhan, C. (2005). Teacher candidates and supervising teachers' opinions about activities of teaching practice in elementary schools. Ankara University, Journal of Educational Sciences, 1(38), 43-71.

Gökmen, Ö. F. (2015). Opinions of prospective and instructional technology education teacher candidates about teaching practice. Mersin University Journal of Education Faculty, 11(1), 96-115.

Göktaş, Z., \& Yanık, M. (2015). Investigation of physical education and sports school students' attitudes towards physical education teaching profession. International Refereed Academic Sports Health and Medical Sciences Journal, 5(16), 39-51.

Hergüner, G., Arslan, S., \& Dündar, H. (2002). Perceptions levels of physical education and sports teaching department students' school experience course. Pamukkale University Faculty of Education Journal, 1(11), 44-58.

İlter, İ. (2009). Investigation of prospective teachers' attitudes towards teaching profession in terms of some variables. Unpublished Master's Thesis. Institute of Social Sciences, Elazı $\breve{g}$.

Ira, N. (2004). School as a system. Cevat Celep (Ed.), As a Profession in Teaching. Ankara: Anı Publishing.

Işıköz, E., Diçer, N., \& Kılınç, Z. (2016). Examination of the relationship between physical education teacher candidates' teaching professional knowledge courses and field knowledge course achievements example of batman university. Batman University Journal of Life Sciences, 6(2\1), 338-346.

Islam, A., \& Imamoglu, O. (2019). Investigation of attitudes of university students receiving sports education towards teaching profession example of ordu university. Manas Journal of Social Research, 8(1), 1313-1324.

Kahyaoğlu, M., \& Ateş, S. (2007). Primary school teacher candidates' views on their professional self-efficacy. Kastamonu Education Journal, 15(1), 73-84.

Kalkavan, A., Kerez, F., Suiçmez, H., \& Bektaş, F. (2001). KTÜ physical education department academic staff and students' vierws and suggestions about physical education teaching. Paper presented at the II. National Physical Education and Sports Teaching Symposium, 21-23 December, Bursa.

Kaya, K. (2004). Attitudes of physical education and sports school students towards the teaching profession. Unpublished Master's Thesis. Gazi University. Institute of Education Sciences. Ankara.

Kaya., H., Ş., \& Samancı, O. (2013). First Impressions of primary school teachers related to communication in school experience course. Ekev Academy Journal, $17(56)$, 419-428.

Keskin, Y. (2013). Evaluation of pre-service teachers' opinions in the process of acquiring professional qualifications: Comparison between religious culture and moral knowledge department and primary education department. Journal of Turkish Studies, 8(3), 319-339.

Ministry of National Education. (1998). Directive regarding the application of teacher candidates in teacher training institutions affiliated to the ministry of national education. Journal of Notifications. Retrieved from http://mevzuat.meb.gov.tr/dosyalar/263.pdf. [Accessed 06.04.2020].

Ministry of National Education. (2014). Teaching areas, assignment and teaching principles. Ankara: Board of Education and Discipline.

Ministry of National Education. (2018). Journal of Communiqué June-Annex, 81(2729).

Oksüzoğlu, P. (2009). Proficiency perceptions of pre-service teacher candidates about teaching profession. Unpublished Master's Thesis. Mersin University Institute of Health Sciences, Mersin.

Ozbek, R., Kâhyaoğlu, M., \& Özgen, N. (2007). Evaluation of pre-service teachers' opinions about teaching profession. Journal of Social Sciences, 9(2), 222-233.

Saritas, M. (2007). Evaluation of the views on the benefits of school experience I application to prospective teachers. Journal of Education Faculty, 20(1), 121-143.

Sharma, S., \& Dhaiya, P. (2012). Comparative study of attitude towards teaching of science and arts of B. Ed. students. Bhartiyam: International Journal of Education \& Research, 1(2), 1227-1255.

Sirin, F. E., Cağlayan, H., \& Cetin, M. Y. Ö. (2007). Difficulties encountered in teaching practice course activity in training physical education teacher a case study. 5th National Physical Education and Sports Teaching Symposium, O2-O3 November, Adana.

Şirin, F. E., \& Cesur, K. (2010). Relationship between physical education teacher candidates' field Knowledge and teaching vocational courses and teaching practice course achievements. THAT. BES Science Journal, 1O(1), 1-10.

Slaybaugh, J., Evans, C., \& Byrd, R. (2004). Second-year teachers attitudes toward the teaching profession. National Forum of Teacher Education Journal. Electronic, 14(3), 31-36.

Taskin, Ö., Baştuğ, G., \& Çetin, M. (2003). A study on the problems faced by Internship physical education teachers. Paper presented at the Physical Education and Sport Social Areas Congress, 10-11 October. Proceedings Book. Ankara.

Unlu, H. (2011). Developing an attitude scale (beoyto) for physical education teaching profession. Educational Sciences: Theory \& Practice, $11(4), 2005-2020$.

Üzüm, H., Yalçın, B., H., Biçer, B., Yüktaşır, B., \& Yıldırım, Y. (2015). Physical education teacher candidates' attitudes towards their profession. Gazi Journal of Physical Education and Sports Sciences, 20(1-4), 1-10.

Yalçın, G. (1999). Importance of practice studies in teacher training and faced difficulties. Unpublished Master's Thesis A.Ü. Social Sciences Institute. Ankara.

Yalız, D. (2010). Comparison of anadolu university physical education and sports teaching department students' attitudes towards teaching profession. CBU Journal of Physical Education and Sports Sciences, 5(1), 7-14.

Yeşildere, S., \& Türnüklü, E. (2007). Examination of students' mathematical thinking and reasoning processes. Ankara University, Journal of Faculty of Educational Sciences, 4O(1), 181-213.

Yetim, A. (2015). Sociology and sports. Ankara: Berikan. 